\title{
唵頭結榜症と㑨頭主等神經この關係
}

\author{
第 1 絽 㘈頭結核症に於ける頸部交威神 \\ 經節特に神經細胞ニッスル氏小 \\ 體の病理組織學的研究
}

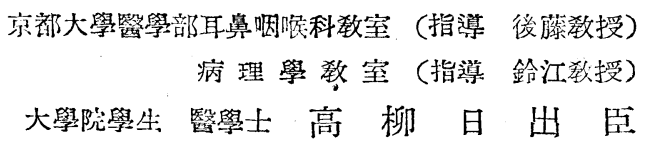

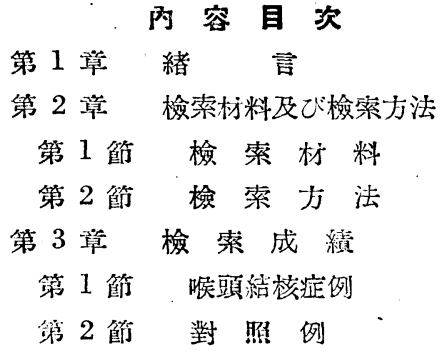

第 4 章總括望に考按

第 5 章 綰 論

主要文献

\section{第1音 緒咅}

交感神經系統の病理組織學的研究は，学ては爾 余の方面よりする各種研究に比し稍々立避れの感 があつたが，1873年 Foa が贸性傳染获に就て研 究を試みて止來漸くその研究は正んとなり，現今 に於ては比較的廣汎に各種疾患に亘つて檢討が行 われ，その研究者数も必すしも少くない。即ち， 傳染性疾患に於ける交感种經節の研究をなせるも のに Lubimoff, Cavazani, D’ Amat , LcignelLevastine, van Gehuchte?, Nelis, Goebel 及び Davidowsky 等があり，その他，精朴﨓に於ける Leignel-Leva-tine, Obregio et Pituleshu, バ ドウ氏病に於けるWilson, 脚氣に於ける咅楠, 長與，中村，本时等の研究をみるがなかんすく Graupner の售稆內分泌臟器疾患に於ける交感利 經系統の變化に關する吥究，Abrikossoff，及 び Mogilnizcky の各種樘染获及び內分泌疾想, Staemmler の動脈硬化症, He: $\mathrm{Z} \cap \underline{g}$, Terplan 及 び大沿の諸程疾忠に於ける研究等を主なるものと する。

然し午ら以上諸家の研究中，絬核性疾患に於け

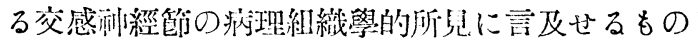

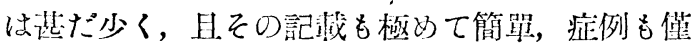
々數例を出ていない。殊に吹嘼紹校症に於ける项

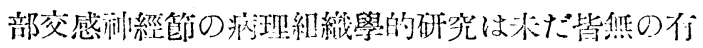
㥞である。

然るに，結核性疾㭧に於ては，植物们絁系統の

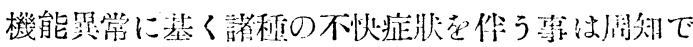

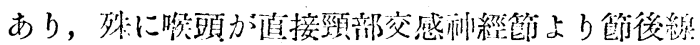

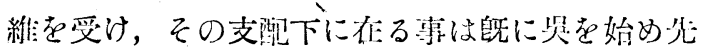

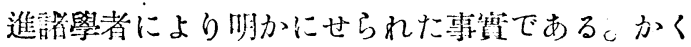

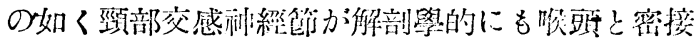
なる關係にある以上，荄部の結核病に於て，们等

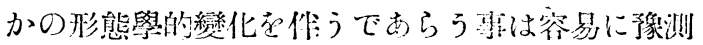

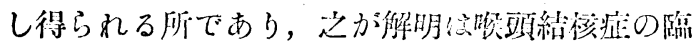

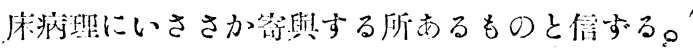
かくて，余は揭題の如き研究在企渔し，いきさか 得る所があつたので，以下順次その成續を讯还し てゆくこととする。

\section{筑 2 音 檢索材料及び澰索方法}

\section{第 1 節 檢 索 材 料}

昭和 23 年 3 月以降, 約 1 年間に旦る京都大學病理學呚

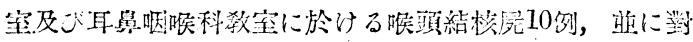

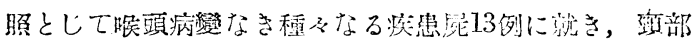

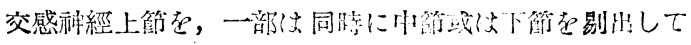
检案に供した。

\section{第 2 節 檢 索 方 法}

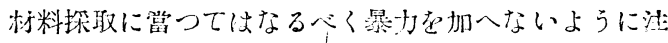

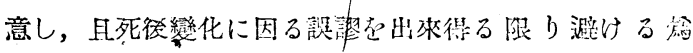
め，氣溫の高い夏季色除く々其に，妏めて死後時間の短 いものから材料在剔出する如く心かけた。かくして得た 材料は直ちにアルコール周定，ッェロイヂン包㙕後10〜 15 ミクロンの切片となし，トルイデンブラウ染色及びへ 
マトキシリッ，エオヂン乗染色尼施して鏡檢しだ。

偷アルコール固定には從來斯ら96\%ェチールアルコー、 ル及び然水アルコールが朋いられているか，余は本研究 に當りメタノールや代用して要も採色在認めなかつた。 但し, メタノールはェチールアルコールに比し, その作 用が强力なる故，漄度を稀め，夫 $390 \%$ 及 $95 \%$ をの を用子れば安全である。又ッェロイヂン溶解及び染色途 中の操作に於ても×タノールを使用して支障老認めなか つた。

\section{第了章 檢 索 成 績}

今，全症例に就き，その詳細なる所見を㑑々に 說述するのは徒らに煩に過ぎ且重複する點が多い ので，茲には代装例數例を擖げるに止め，他は表 を以て示す事とする。

\section{第 1 笁 喉頭結核症例}

第 1 例 (症例番號 5)：28歲，男，死後8時間

（1）喉頭肉跟的所見：喉頭蓋は乎術に依り缺如。甲 狀軟骨は截痕部に於て大豆大に缺損, 軟举露出し, 前內

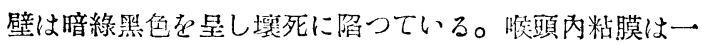

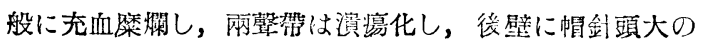
回形穿孔認める。

（口）融經節病理組織學的所見：間筫結䋨織量は年齡

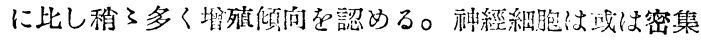
し或は䠅性に配列分有し，疏密の差か汸なり著明であ る。細胞は大さ中等大もしく㥙るれよ゙り秒了大なるもの

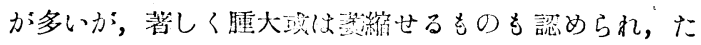

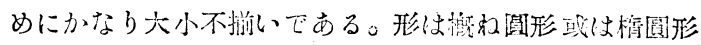
もしくは民れに颣するか，不正多角形走示すものも少く

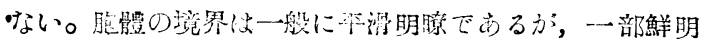

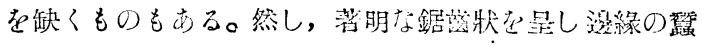
食せられたる如きもの仯い。

核は丰として圆形，中央より稍了偏在するものが多い

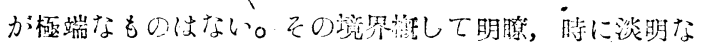

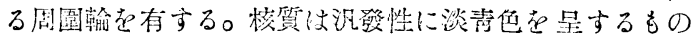

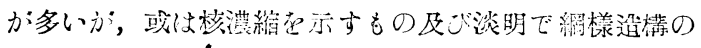
明かなものも認められる。核仁は明暸, 榄の㕷了中央に 位置する。

虎斑は大多數の細胞に於て崩境している。郎ち, 胞 體の沉發性に濃或认淡毒色赤するのが多いか，乙の 他，歴埃狀に崩坮せるもの，粗大顆粓狀をなするの，部 分的に染色筫激解して淡明なるもの, 多数の不炾則な形

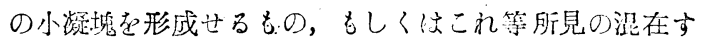
るもの等多樣である。更に少稘の細胞に空泡變性老認め る。空泡は土として胞䯠息緣部のみに登現せるものが多 いか，又明かに胞體內部に存在し，染色質は虭網狀に相
連なつて所謂蜂穼栐造構を示すものがある。又これ等の 細胞とは别個に, 核仁候如し, 淡青色の核寺有し, 原形

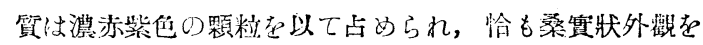
量する小細施办消散在するの在引る。何原形質內に黄褐色 り色素淡着芭隶せる細胞方少くない。

被膜細胞に萻戀はないか，間貿中の小血管稍了充盈 し，輕度の’水蕾を件い，血管周圍に当として 淋巴球及び 少數の大圓形細胞よりなる細胞浸潤を認める。

以下の症例に於ては，神經細胞の形狀，邉綵の狀態前

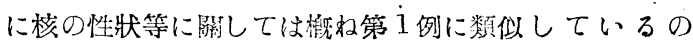
で, 必要以外は之を省略する。

第 2 例(症例番號 21)：34歲, 男, 死後19時間

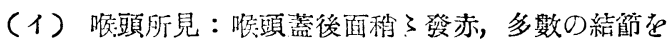

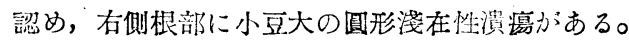

（口）神經節所兒：間質䋨締緎堆殖し稍了多量, 神經 細胞は著しく腫大或は菱縮して核洦縮を是し，大さ甚だ 不揃いとなり分布に疎密の差を認める。ニッスル氏小體 は局部的に正常に近い所見点呈するものも少數あるが，

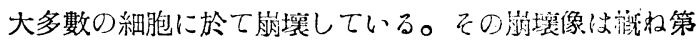

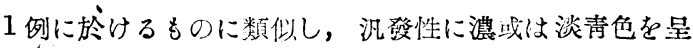
するもの及び微細顆粒狀乃至壁埃狀に崩壤せるもの多

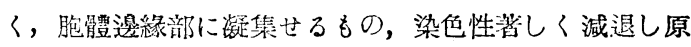
形筫の綿雲狀もしく《微細顆档狀寺呈し，胞體境界明瞭 を缺き，棪は僅かにその遺證物を眙すか或は全く消失し て所謂除影像在是するものもある。

空泡變抄も少数の細跑に䋨すられ，且かなり多數の細

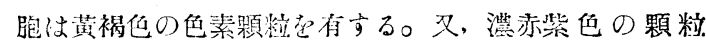

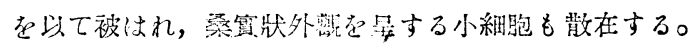

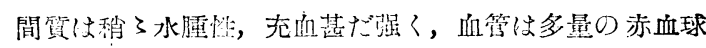
及び多核白血球老以て充され，非としてその周園に中等

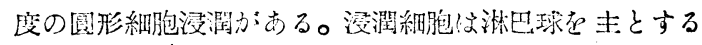

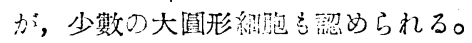

第 3 例(定例番號27)：45笠，男，死後12時間

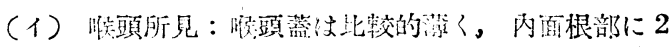

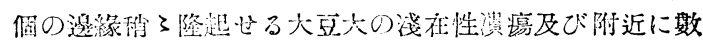

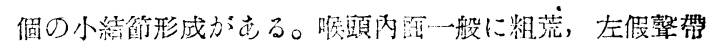

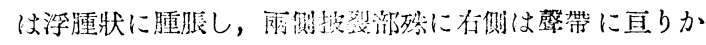

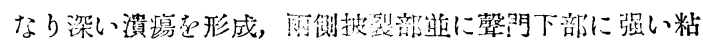
膜下出血起認める。

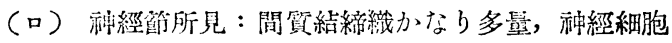
はかなり大小不揃いであるが，分布の踈密差は輕度であ

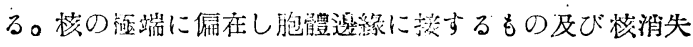
し陰影化せる細胞も哂められる。挤斑は比皎的良了保持 されている細胞も少くないか，大多数の細胞に於て崩壤 强く，空泡變性も少稘のものにみると共に，桑筫狀の小

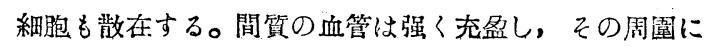


まとして淋巴球及び少數の大圓形細胞よりなる 細胞浸潤 老認めるが水腫は件わない。

第 4 例(症例番躆 30 )：13歲，女，死後1封間

（1）喉頭所胃：喉頭蓋は大部分缺損，軟骨力露出し ている。喉頭粘瞙一般に粗荒，雨側共に假馨帶より报裂 部に亘り潰湯化し著しく䝷血性，兩侧馨門下部に小指頭 大の淺在性潰瑒がある。

(口) 神經節所見：間質結䋨織は少量で揞殖圭認めな い。神經細胞は大さかなり不揃いであるか，分布に踈密 の差は殆ど認めない。胞體の邊緣は溉的本滑明镱である
か，局部的に鮮明を祙き染色質の溘出せるものがある。 核は多?は單核性であるか，2核性，3核性のものも少

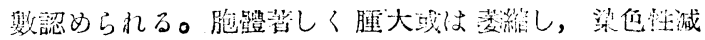

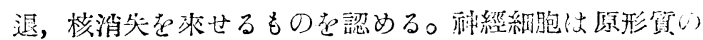

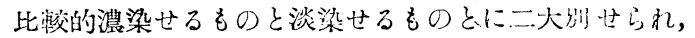
虎斑の像一見正常に近いものも少くないか，これ等も精 細に観察する跱は全く正常像ではなく，その配列踃く不

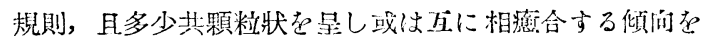

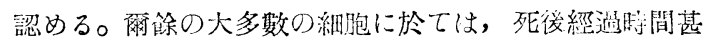
だ短きに拘わらす，原形斦の汎發性に淡染せるもの，粗。

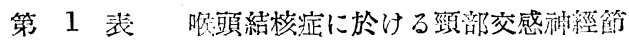

\begin{tabular}{|c|c|c|c|c|c|c|c|c|c|c|c|c|c|c|c|c|}
\hline \multirow[b]{2}{*}{$\begin{array}{l}\text { 症 } \\
\text { 例 } \\
\text { 番 } \\
\text { 號 }\end{array}$} & \multirow[b]{2}{*}{$\begin{array}{l}\text { 年 } \\
\text { 齡 }\end{array}$} & \multirow[b]{2}{*}{$\begin{array}{l}\text { 性 } \\
\text { 別 }\end{array}$} & \multirow[b]{2}{*}{$\begin{array}{l}\text { 死 } \\
\text { 後 } \\
\text { 時 } \\
\text { 間 }\end{array}$} & \multirow[b]{2}{*}{$\begin{array}{c}\text { 探 } \\
\text { 取 } \\
\text { 月 } \\
\text { 日 }\end{array}$} & \multicolumn{7}{|c|}{ 神 經 笛 細 胞 } & \multicolumn{2}{|c|}{ 間 } & \multicolumn{2}{|c|}{ 質 } & \multirow[b]{2}{*}{ - 備 } \\
\hline & & & & & $\begin{array}{l}\text { 配 } \\
\text { 列 } \\
\text { 䠅 } \\
\text { 密 } \\
\end{array}$ & $\begin{array}{l}\text { 大 } \\
\text { 小 } \\
\text { 不 } \\
\text { 揃 }\end{array}$ & 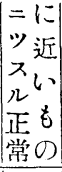 & 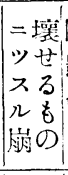 & 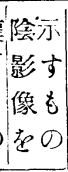 & 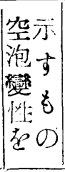 & $\mid \begin{array}{l}\text { 迅む } \\
\text { 素る } \\
\text { 沈も } \\
\text { 着の }\end{array}$ & 殖 & 血 & $\begin{array}{l}\text { 水 } \\
\text { 腫 }\end{array}$ & 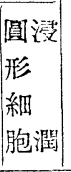 & \\
\hline 5 & 28 & & 8 & $12 /$ II & + & th & - & $\mathrm{HH}$ & $1+$ & + & H & + & H & + & + & 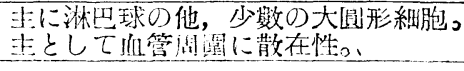 \\
\hline 9 & 35 & 占 & 9 & $24 /$ II & + & H & + & $H$ & + & H & 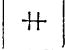 & + & + & H & + & \\
\hline 15 & 21 & $\hat{\delta}$ & 17 & $5 /$ 而 & + & H & - & $\mathrm{H}$ & + & H & + & + & \# & + & H & 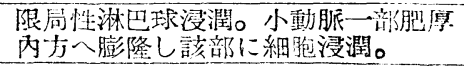 \\
\hline 17 & 26 & $\hat{\delta}$ & 17 & $-10 / \mathrm{V}$ & + & H & - & $H$ & + & $H$ & $H$ & + & H & + & + & \\
\hline 19 & 22 & 今 & 15 & $14 / \mathbf{V}$ & + & H & - & $H$ & H & H & + & + & H & + & $H$ & 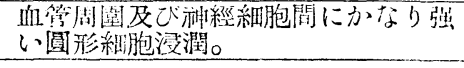 \\
\hline 21 & 34 & $\hat{\delta}$ & 19 & $21 / \mathrm{V}$ & + & H & - & $\mathrm{H}$ & + & $H$ & $H$ & + & $H$ & + & H & \\
\hline 22 & 23 & $\hat{\delta}$ & 2 & $18 / \mathbf{X}$ & + & $H$ & + & H & + & + & + & + & $H$ & + & + & $\begin{array}{l}\text { 䒠に淋巴球の他，少數のプンズマ細 } \\
\text { 胞。 }\end{array}$ \\
\hline 27 & 4.5 & $\hat{\delta}$ & 12 & $23 / \mathbb{I}$ & + & H & + & $H$ & + & + & H & + & H. & - & $H$ & \\
\hline 28 & 42 & $\widehat{\delta}$ & 7 & $9 /$ III & + & + & +1 & H & + & + & $H$ & + & + & + & + & 淋巴球の他多核白血球。 \\
\hline 30 & 13 & 우 & 1 & $24 /$ II & - & $H$ & + & H & + & + & + & - & $H$ & + & H & 溇巴球の他，多核白血球。 \\
\hline
\end{tabular}

大顆粒狀或は麼埃狀に崩壤せるもの，局部的に㠜集せる もの等種々のニッスル崩堙像を是する。

煠泡變性も極めて少數の細胞にみる。空泡は大なるも のはなく，主として胞體遥緣部に存在するか，又原形筫 の蜂穼樣造構を呈するものがある。桑賽狀小細胞も散在 する。黄褐色の色素沈着はただ少數の細胞にだけ認め る。間質に於ける充血はかなり强く，一部に小出血を作 い, 輕度の水腫前に中等度の血管周图圆形細胞浸潤があ る。淋巴球の他, 少數の多核白血球か混在する。

爾餘の定例に於ける所兒は第1表に示す通りで ある。

これ等10症例は, 死後經過時間 1 洔阿乃至19時

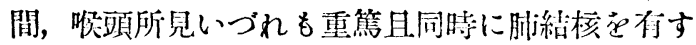
ろが，更に啊颔結核を合併せるもの3例（No. 5. 22. 25), 腸結核を合併せるもの1例 (No. 9), 經
過中粟粒絬核により死亡せるもの1例 $(N \circ .30)$ で

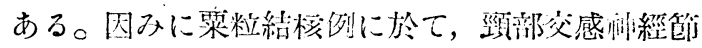
が肉腿的に稍々漖明に腫大し，僅かに淡紅色在!

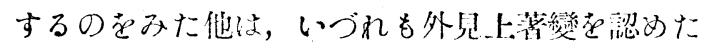
ものはない。

\section{第 2 章 對. 照 例}

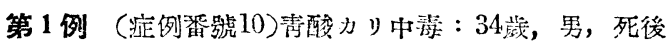
18時間。

神經節所見：間筫結䋨織增殖。神經細胞はかなりその 數少く，大小不拼いか落しいか分布に踈密の差はない。

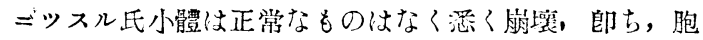
體嚺緣部或は內部に局部的に粗大塊老形成するすのが多

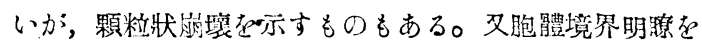

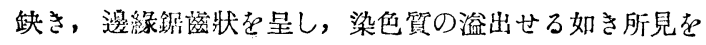
呈する細胞か少くない。空泡變性は少散の細胞に認めら 
れるか，陵影化せるものはな。又被膜細胞增磒し，內 部は淋巴球樣細胞其合し, Terplan の所謂 Knötchen 像 虽するもの品ある。淡黄褐色の色素沈着は少數の細胞 に認められるのみ。間貿仙稍了水腫性，充血强了，血管 周圈に甚げ强い圆形細胞浸潤を認める。声として淋巴球 であるが多核白血球も混在する。

第 2 例 (症例番號16)空洞性肺結核: 27歲, 男, 死後 26 寺間。

神經節所見：間筧結締織は谌だ多量，年龄に比し明か に㘿殖。神經細胞はこの數極めて少く且平等に分有して いる。大さ概ね中等大，若于の細胞は胞體著しく縮小し 被膜下に大なる空陣を形成するが，特に腫大せるもの少

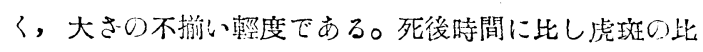
較的良了保持せられているものも少くないか，爾狳の大 部分の細胞はニッスル崩壤が認められる。郎ち, 胞體汹

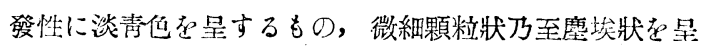

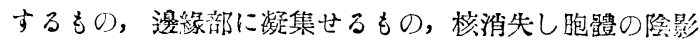
化せるもの等せ認める。空泡戀性は認められない。色溸 沈着は少數の細胞にみるのみ。間質に於ける血管心中管 度に充盈, 淋巴球及び少數の大圆形細胞上りなる細胞浸 潤范認めるが水腫はない。

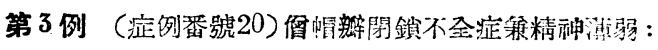
46歲, 女, 死後39時間。

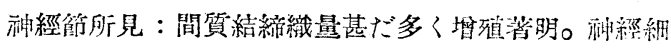

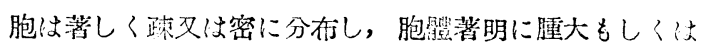
䔀縮せるもの抄くない。從つて大さ罡だ不撤い, 形を 不䙺則なもの办多い。虎斑は比較的良了保持せられてい

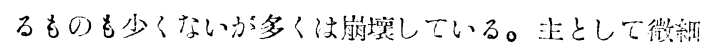

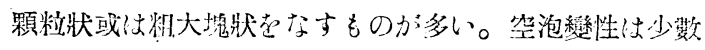
の籶胞に於て滛緑部に僅ふに認められるに過ざない。死

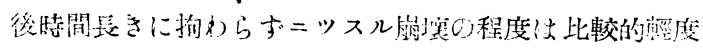

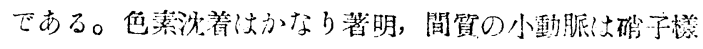

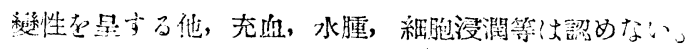

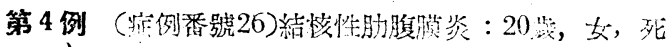
後 2 時閌。

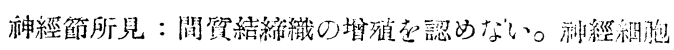
の配列眥密の美及び大さの不揃いはない。ニッスル式小

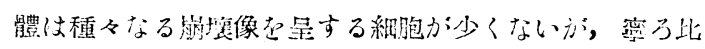

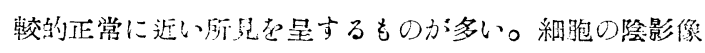

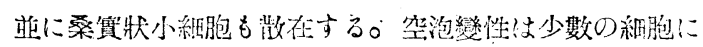

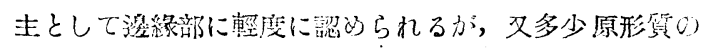

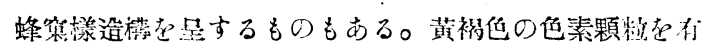
する細胞に少數に過ぎい。間琶には充血, 水腫, 祖胞 浸潤等は認められない。

爾余の對照例に於ける所見は第2 表に示す如く
である。

\section{第 4 章 總括並に考按}

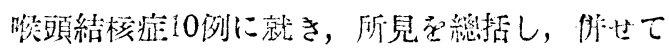
敖照例と比較考察することとする。

1) 湤經細胞の變化

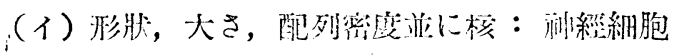

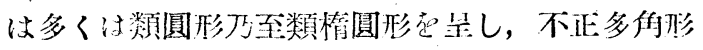

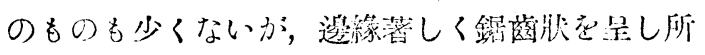

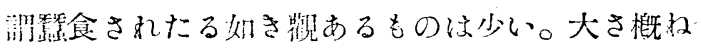

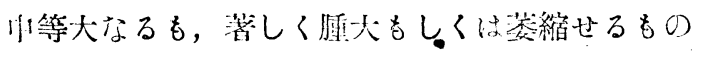
も少からす湢倠し，全例に於て火さ不揃いかなり 著明である。然るに，對热例に於ては約乎数に之 范みるのみ。その程度も輕いものが多い。

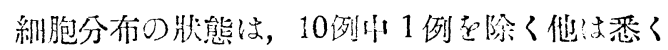

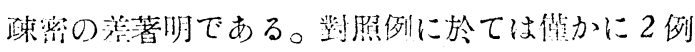
に党認めるに過ぎない。

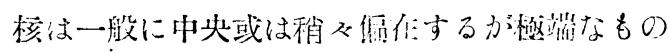

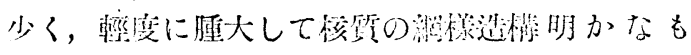

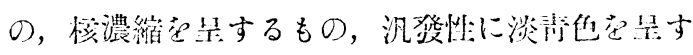
るもの或は淡明な核周国翰尼行するもの等があ

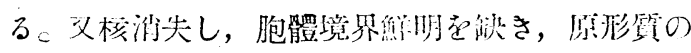

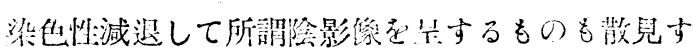

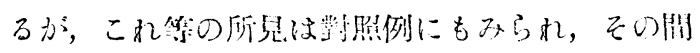

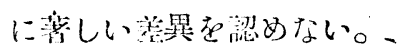

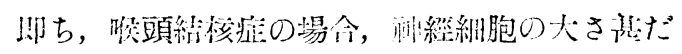

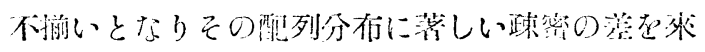

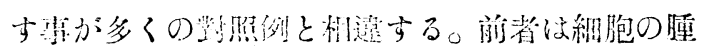

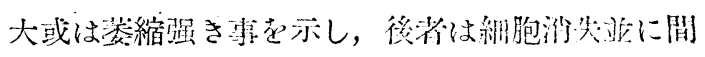
留增殖花示すものと解せられる。

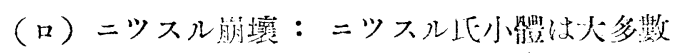

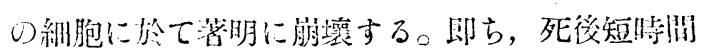
例に於ては一見虎斑の比较的IE常像に近い所边

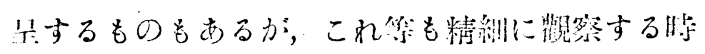

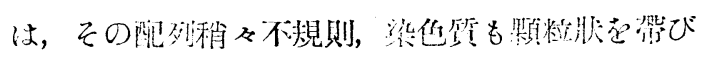

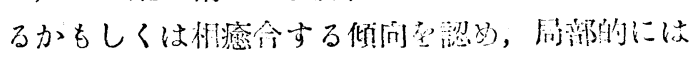
多少其䐓壤せるものが多い。しかもかかる變化轱

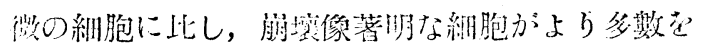

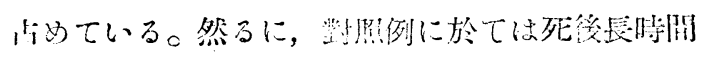
のものに於てすら變化のうしい絸胞が少くないも

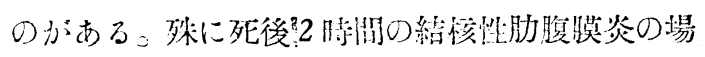

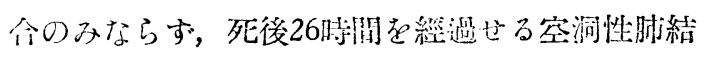
核の埸合に於てすら虎斑の崩壤著明な綝胞少きに 


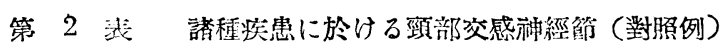

\begin{tabular}{|c|c|c|c|c|c|c|c|c|c|c|c|c|c|c|c|c|c|}
\hline \multirow[b]{2}{*}{$\begin{array}{l}\text { 症 } \\
\text { 例 } \\
\text { 番 } \\
\text { 號 }\end{array}$} & \multirow[b]{2}{*}{$\begin{array}{l}\text { 年 } \\
\text { 齡 }\end{array}$} & \multirow[t]{2}{*}{ 怢: } & \multirow[b]{2}{*}{$\begin{array}{l}\text { 死 } \\
\text { 後 } \\
\text { 時 } \\
\text { 䦓 }\end{array}$} & \multirow[b]{2}{*}{$\begin{array}{l}\text { 探 } \\
\text { 取 } \\
\text { 月 } \\
\text { 日 }\end{array}$} & \multirow[b]{2}{*}{ 病 } & \multicolumn{7}{|c|}{ 神 經 節 細 胞 } & \multicolumn{2}{|c|}{ 䦥 } & \multicolumn{2}{|c|}{ 質 } & \multirow[b]{2}{*}{ 備 } \\
\hline & & & & & & $\begin{array}{l}\text { 配 } \\
\text { 列 } \\
\text { 柾 } \\
\text { 密 } \\
\end{array}$ & $\begin{array}{l}\text { 大 } \\
\text { 小 } \\
\text { 不 } \\
\text { 揃 }\end{array}$ & 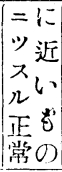 & 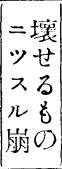 & 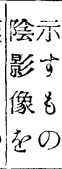 & 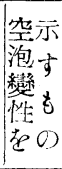 & $\begin{array}{l}\text { 色あ } \\
\text { 素る } \\
\text { 沈 } \\
\text { 着の }\end{array}$ & 磌 & 充 & $\begin{array}{l}\text { 水 } \\
\text { 朠 }\end{array}$ & 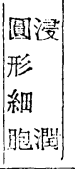 & \\
\hline 4 & 22 & $\hat{\delta}$ & 13 & $5 /$ 咕 & |ブロバリン中毒 & - & tit & + & $+t$ & + & H & + & - & - & - & - & \\
\hline 6 & $4)$ & 우 & 27 & $20 /$ 直 & |網壯織細胞肉腫症| & - & + & + & H & - & + & H & + & - & - & - & \\
\hline 7 & 34 & 今 & 6 & $22 /$ III & 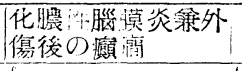 & - & - & +1 & + & + & + & + & - & H & + & + & $\begin{array}{l}\text { 㴆揤細胞は淋巴球の } \\
\text { 他少許の多核白血球 }\end{array}$ \\
\hline 8 & 46 & 우 & 11. & $23 /$ III & 海怔中毒 & - & -1 & $H$ & + & - & + & H & + & + & + & + & 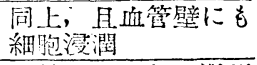 \\
\hline 10 & 34 & $\hat{\delta}$ & 18 & $25 /$ II & 青酸力リ中复 & - & +4 & - & Ht & - & + & + & + & it & + & $\mathrm{HH}$ & 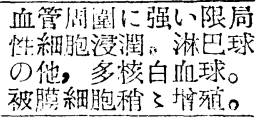 \\
\hline 11 & 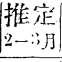 & $\hat{\delta}$ & $\mid$\begin{tabular}{|c|c|}
$f$ \\
24
\end{tabular} & $26 /$ III & 捨于 & - & - & $H$ & + & - & +1 & - & - & - & - & - & $\cdots$ \\
\hline 12 & 36 & $\hat{\delta}$ & 9 & $27 /$ II & 骨盤肉腫 & - & - & H & + & + & +1 & + & - & - & -1 & - & . \\
\hline 13 & 61 & $\hat{o}$ & 16 & $27 /$ II & 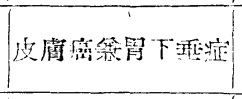 & - & - & H & + & - & + & WH & + & $H$ & + & + & 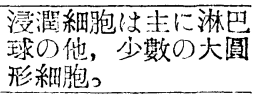 \\
\hline 14 & 28 & 우 & 22 & $1 /$ III & 胃痤 & + & $H$ & + & $H$ & itt & $H$ & $H$ & + & - & - & - & \\
\hline 16 & 27 & $\hat{\delta}$ & 26 & $10 / V$ & 空洞性肺䋨輆 & - & + & Ht & + & + & - & $H$ & + & H & - & + & . \\
\hline 18 & 37 & 우 & 4 & $14 / \mathrm{V}$ & 腦腫瘍 & - & $\mathrm{H}$ & - & H & - & + & $\mathrm{HH}$ & + & $H$ & + & +1 & $\begin{array}{l}\text { 淋巴球少數のプラズ } \\
\text { マ細胞上なる限局 } \\
\text { 性細胞浸潤。 } \\
\end{array}$ \\
\hline 20 & 46 & 우 & 39 & $16 / V$ & 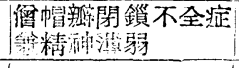 & $H$ & $\mathrm{HH}$ & H & + & + & + & $H$ & + & - & - & - & 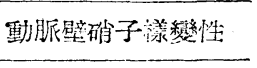 \\
\hline 26 & 20 & 우 & 2 & $16 /$ II & 结被性肋腹䑏资 & -1 & - & $H$ & + & + & +1 & + & - & - & - & - & \\
\hline
\end{tabular}

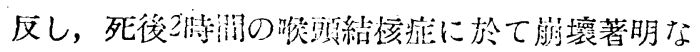

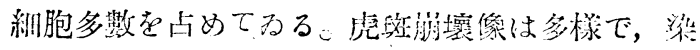

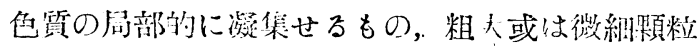

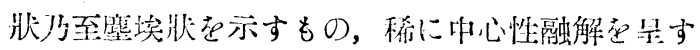
るもの等市るが，一般に㵀融絬核症の場合には， 大多數の對照例と買り，原形質の沉發性に渨或は

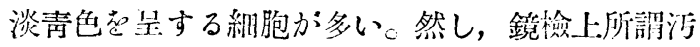
なく不快感死抱かしむるもの济い。

（八）空泡變性：全例に認好る。空泡は主とし て胞體逶總部に份在するか，又明かに胞體內部に 传在し，稀にその大部分を占據し，ために恰も脂 肪絒胞の如き觀存昱するものがある。又原形質の

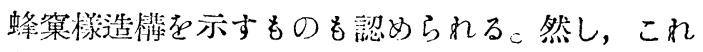

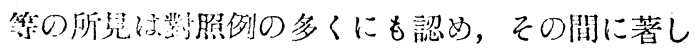
い望罢はない。

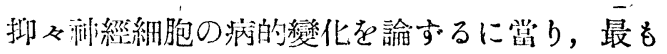
注意すべきは死兴變化，なかんすく屍性變化であ るが网都の區别は必すしも可能ではない。死後變
化の發現時闒に就いては從來諸萣の研焭がある。 即ち, Neppi は死後變化の發現は死後 48 時間と し，兒玉は氣溫15〜 $0^{\circ} \mathrm{C}$ に於て10時间， $0^{\circ} \mathrm{C}$ に於 て16時间と云い, Faworsly, 安藤, 模本等以普

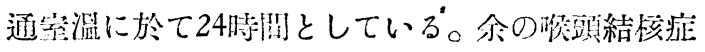
例はすべて夏季を除き且死後19胡间以內のもので

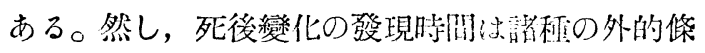

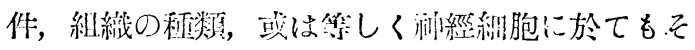
の種類により區くであるから，これ等势芜の望驗

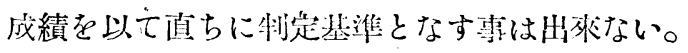

次に死後戀化と获的變化との區別に關して は次の如き㒛說がある。即ち，Philippe 及び Gotherdは死娞變化の際には润經細胞は形態の “變化及び核の偏位はなく，原形質は问質性となり

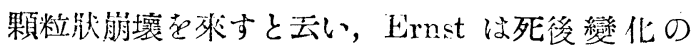
特徵として核の縮小，原形筫の汹發性着色及び中 心性崩壞を舉挤ている。Faworsky は死後變化 特有の所見として，染色質の沉發性顆粒爿崩壞及 
び胞體境界の繁食像を舉げ， Marinescoは死後 變化の際に心緗胞體】び核の腫脹を來す事なく，

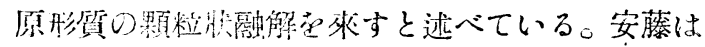
死後變化の場合には形態の變化極めて不規則，着

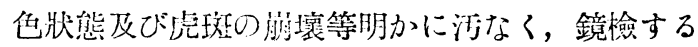
腿をして不快を感ぜしむると云い，兒玉はニツス

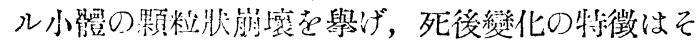
の變化發现の愐标が多㥞且不規则で，死後變化を

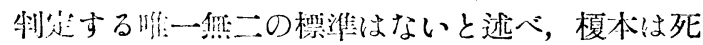

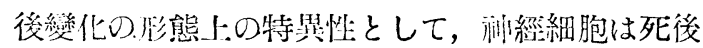

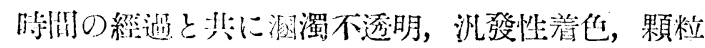

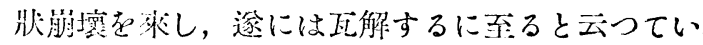
る。

要之，死後戀化と病的變化との區別に關しては 諸渷があり，確たる物定基蕉はない。然し，喉 頚結核症の場命，死媱僅かに1時間後のものに

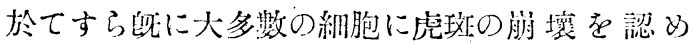

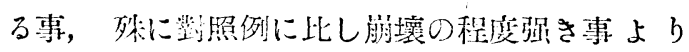
污へるならば，死後變化芷全く除外する事はH 隶ないが明加病的變化方主なるものと認める゙る 尼得ない。

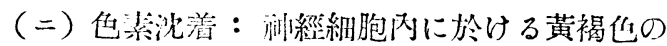

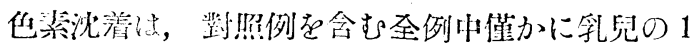

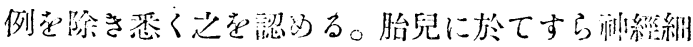

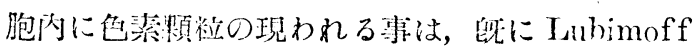

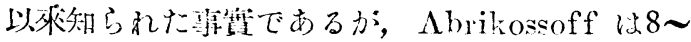
10才後始的て現われると云い，Graupner 惟进 な青尔に現われると科し， Lcionel-Ievastine は

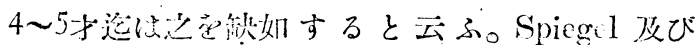

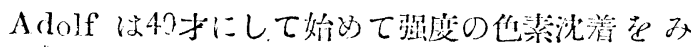

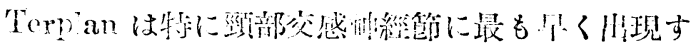

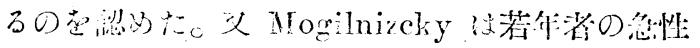

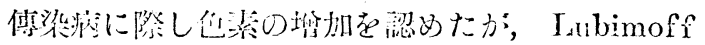

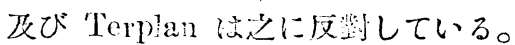

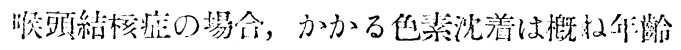

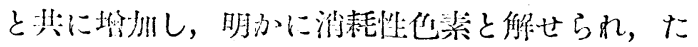
だ26才の1例に於て異常に多量なるを㑇めたに過

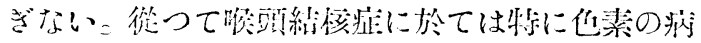

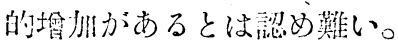

2) 閒質の變化

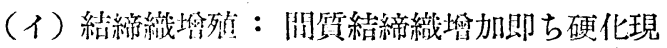
象を I.eignel-Tevastineは3型に分類したか，“元
来絬締織は生理的に年路と共に塯加し，多に老人 には殆ど繁常認められる現像である。袋颚結核症 の場合，第 1 表に示す如く年第に比し稍及蕾殖傾

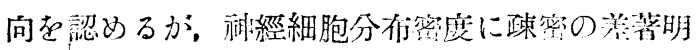
なる事並に大小不揃い蒈だ强き事上り明ふに多少

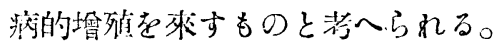

（口）充血並に水腫：喉喕絬核症の場会，殆ど 全例に涊める。立血想しき時は, 血管收多量の赤 血球及び多核白血球で充される。多に21才の 1 例 に於て，動脈壁一部队䐩へ膨隆肥厚し，核部に少 數の圓形細胞浸澗を認めたものがあるが，一般に 血管壁に著變はない。ただ瞥帽弁閉鎖不全症例に 於て，血管壁の硝子樣變性と絬締織の著明な㙫列! とを認めたに過ぎない。

（八）䋚胞浸潤：喉頭結核症に於ては，主とし

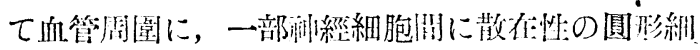

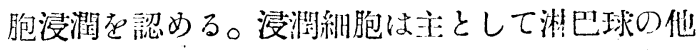
桨干の大圆形細胞も混在し，明かに多核白血球や プラズマ細胞の認められる事もある。然し，青該

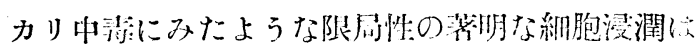
衿多ない。

Abrikossoff は，かかる浸淜組胞の利類は琙 疾悲に特仍で結核は淋巴球浸潤を特徵とすると述

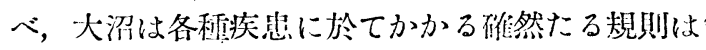
認められないとしている。余の對照例に於ても光 血前に圓形細胞浸阔を認める埸合がある。この埸 今，多核白血球或はプラズマ絒胞を認めるものも あるが主なるものは矢張り淋巴球である。從つて 淋巴球浸潤を以て喉喕絬核症の特徵とは云い得な い。メ Abrikossoff はかくの如き血管周国細胞

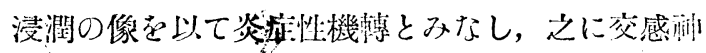
經䬦炎 (Sympatho-ganglionitis)なる名称を與へ Staemmler 大沼等も之に賛成している。食も间

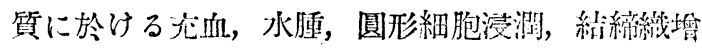

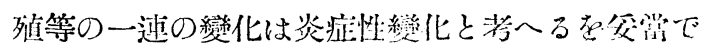
あると思惟する。

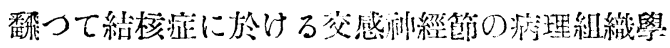
们變化に就ては, Mogilnizcky は泟縒縕胞の減 少，蔺質增殖，强き沦血，ニツスル小揾の粉末师 奱化，中心性融解，核漂縮，㤥分解及び沉發性撯 色來來すと云い，Abrikossoff は㴬經細胞の造

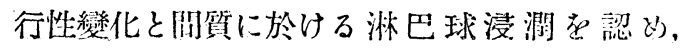


Leignel-Tevastine は腹部交感种經節に局所炎症 反應及び中毒性細胞障害，色素沈着，細胞萎縮等 就明した。喉頭絬核症の場合，これ等諸氏の見 解に類似し，洞經細胞の種々なる退行性變化と間 質に於ける炎症性變化とをみる。蓝し喉頭絬核症 が肺絬核に續發するものである以上當然である。 然し，かかる變化は對照例に徵しても明かな如 く，結核のみならす他種疾患に於ても認められ， 決して喉頭絬核のみに特有なものではない。丈大 沼は絬侅は林經細胞の退行性變化よりも，血管結 締織に於ける炎性細胞浸潤を主とするとしている が，喉頭絬核の場命，兩種の變化は相浒立しいづ れを主であるとする事も出隶ない。然し，唝頭結 核症に於ける栭部交感秗經節の變化は，他の結核 に比し强度なる事は明白である。かかる事實は, Mogilnizcky の交感䏡經節の變化は罹患臟器に 近い神經節に於てょり一層强いとする主張と符合 し，興味ある事と云わねばならない。

さて，交感神經系統の病理組織學的所見並に その意義に關しては，從來研究者間に意見の一 致をみない。Abrikossoff, Mogilnizcky 及び Staemmler 等は, 該病變を以て直ちに種をの植物 性機能障碍に對して意竜ありと考へ, Graupner Herzog 及び Terplan は自重說を唱へ, Spiegel 及び Adolf は中立の立場を持している。

然るに，喉頭結核症の場合のみならす，單に肺 絬核症の場合にも往及喉頭乾燥感を訴人る事があ り，組織學的に喉頭笳亚に腺の萎縮を認める事か; あろのは，關根及び端の多數の剖檢例を俟つ迄も なく日常屢々みる事實である。文 Lewan lowsky は交感神經節の剔出或は節後總維を切斷する時 は，末梢部は興奮性立進の爿慜に陷ると述へ，义 一部の反對はみるが Onod, Broeckaert, Dono frio，伊藤，一丸並に柴等により喉頭筋の交感神 經性支配が立證せられてるる。これ等の事實より 项部交感神經節に於ける形態學的變化か，椥頭局 所に瑟影響を與へて該病變を增惡せしめ, 病變の 惡化は神經篩に於ける變化を進展せしめ, 所謂因 果循環を招來するものと考へても敢て多くの誤り はないものと信する。

\section{第 5 章 結}

論

（1）神經細胞ニツスル氏小體染色に際し，固定
及びその後の操作にメタノールを代用するも毫も 支障を認めない。

(2) 喉頭結核症に於ては，栭部交感利經節は肉 眼上著變なく、結核性變化を認めたものはない。

(3) 喉頭絬核症に於ては，项部交感杉經第は种 經細胞の退行性變化（腫大，萎縮，消垁，二ツス ル崩壞，空泡變性）と間質に於ける炎症性變化(絬

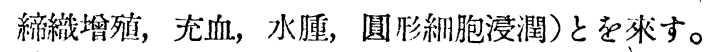

(4) 兩礌の變化は相倣立し，いづれ草である とする事は出秋ない。

（5）かかる變化は喉頍綃核症のみに特有のもの ではない。然し，頸部交感神經節に於ける變化は 朋かに他の絬核の場合に比し强度である。

（6）頸部交感种經篩に於けるかかる形態學的變 化は，喉顽結榜症に惡影響を與へて之を增惡せし め, 局所病變の琶化は榊經篩に於り万變化を强か らしめ, 所謂因果循環を示すものと考へられる。

(本論女の要旨は第20回結核研究會に於て發表した)

\section{主要文 献}

1) Spielmeyer : Histopathologie des Nervensystems (1922)

2) Müller : Lebensnerven u. Lebenstriebe (1931)

2) 吴 : 自律种經柔(昭10)

4) Cavazani : Uber histol. Alteration d. Sympathi cus bei Infek. krh. u. Intoxikationen (Referat) Centralblatt f. allg. Patholog. u. pathol. Anat omie Bd. 5. 1894)

5) Graupner : Beiträge zur morm. u. patholog. Anatomie d. sympath. Ns. (Zieglers Beiträge Bd. 22. 1898)

6) Abrikossoff : Die pathol. Anatomie d. sympath. Ganglien (Virchows Archiv. Bd 240. 1923)

7) Mogilnizcky : Die Veränderungen d. symp. Ganglien bei Jnfekt. krh. (Virchows Archiv Bd. 241. 1923)

8) Staemmler : Zur Pathol. d. symp. Ns im bes. über seine Bedeutung. f. die Entstehung d. Arteriosklerose (Zieglers Beiträge Bd. 71. 1923)

9) Terplan: Zur Frage histopathol. Veränd. in symp. Ganglien u. deren Bedeutung (Virchows Archiv. Bd. 262. 1926)

10) Herzog : Beitrag zur norm. u. pathol. Histol. d. Sympathicus (Zeitschrift f. ges. Neurol. u. 
Psychiatrie Bd. 103. 1926)

11) Filatowa u. Lawrentjew : Über d. pathol. Histol. d. N. u. Ganglien bei (Kehl-u. Lungen tbc. (Virchows Arch. Bd. 286. 1932)

12) Terracol : Diè symp. Innervation d. Kehlkopfes (Centralblatt f. H-N-O-Heilk. Bd. 31, 1938)

13) 本田：脚氣に於ける神經系統の變化に就て,

(醫事新聞 $870 \sim 872$ 號，大 2 )

14) 長與：脚氣(醫事新聞872 877號，大2)

15) 中村：急性脚氣に於ける交感神經所見，（神經 誌, 17兊, 大7)

16）高楠：脚氣前に沜白米病に於ける神經節細胞の 變化，(神經誌，24兊，大13)

17) 大沼・交感神經系統の正常前に病理租織學的研 究; (神經誌, 30 忩, 昭4)

18）新井：小神經細胞とニッス几染色物質业に ス几染色體の生物學的意義知見補遺，（䒬經誌 23卷, 大 12 )

19）下田：神經細胞病理解剖知見補遺（神經誌，14 卷, 大 4 )

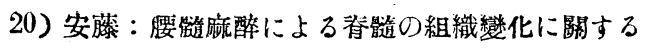
䁈驗的研究，(岡䂑誌，316號，大5)

21) 榎本：腐敗組樴の研究特に神經組織の腐敗に關。 す万研究, (京都醫學雜誌, 31 卷, 昭9)

22）掛下：交感种經力啹頭に及添す影響に就て 大 日耳.界, 32兊, 大 15 )

23) 伊藤：㗋頭筋の自律神經支配に就きて（神經誌 29卷, 昭 3 )

24) 同上：喉頭筋の交感渱經性榮荃支配に就て（大 日耳畀，34兊，昭4)

25) 柴：食道前に喉頭筋に於ける神經終末に就て， (東醫誌, 43卷, 昭 4 )

26）一丸：上頸交感神經節剔出後に於ける喉頭筋の 禁化に就

27) 鈴木：迷走神經 $\zeta$ 頚部交感神經の關係（東醫誌 49 兊, 昭 10 )

28）澄川，中岛：頉胸部交感种經切除出に迷走神經 频部切除の䁈驗的肺結核前に肺炎に及汪す影響 (日本外科誌, 40 回, 昭14)

\section{品質第ー・ゲンブの醫藥}

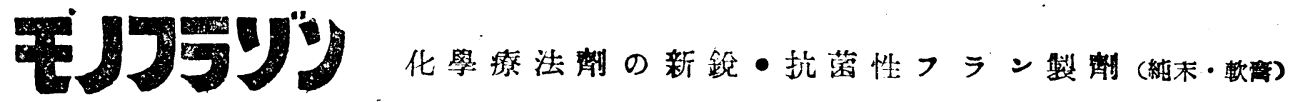

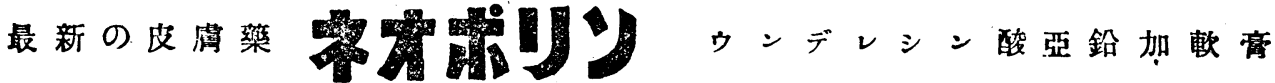

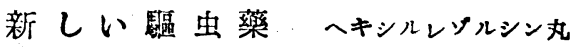

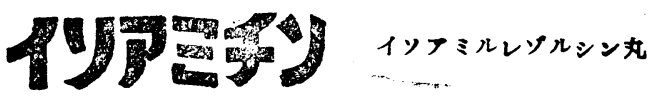

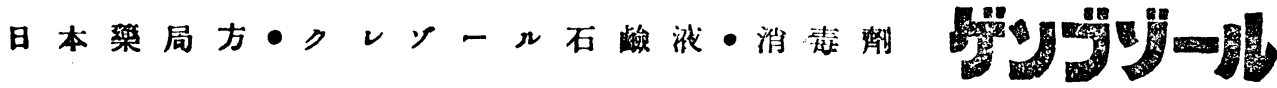
第一工業製藥株 式會 社 （文献揆星） 京都市下宗區七钭千本苚 